\title{
From Public Policy to Equity and the Constitution. Are Mexican Women Still Invisible?
}

\author{
Nancy Guzmán-Raya ${ }^{1}\left(\mathbb{C}\right.$, Martha Leticia Guevara-Sanginés $^{2}{ }^{(0)}$, \\ Ariadna Crisantema Martínez-Hernández ${ }^{2}$ (i) \\ ${ }^{1}$ Universidad de Alicante, Alicante, Spain \\ ${ }^{2}$ Universidad de Guanajuato, Guanajuato, Guanajuato, Mexico \\ Email: nguzmanr@gmail.com
}

How to cite this paper: Guzmán-Raya, N., Guevara-Sanginés, M.L. and MartínezHernández, A.C. (2019) From Public Policy to Equity and the Constitution. Are Mexican Women Still Invisible? Open Journal of Social Sciences, 7, 206-222. https://doi.org/10.4236/jss.2019.76017

Received: May 20, 2019

Accepted: June 24, 2019

Published: June 27, 2019

Copyright () 2019 by author(s) and Scientific Research Publishing Inc. This work is licensed under the Creative Commons Attribution International License (CC BY 4.0).

http://creativecommons.org/licenses/by/4.0/

\begin{abstract}
In Mexico, the political and social rights of women have been acquired slowly and in a limited way; this is a sign of their invisibility. Some rights such as voting and running for election, education and work are all signs of progress. However, in practice, the visibility of Mexican women has been limited to their reproductive, family and domestic functions. This is reflected from the legal aspect-where constitutionally it has taken time to be recognized as citizens - to daily life, as their possibility of choice in educational opportunities, work and personal decisions such as motherhood. Through documentary review, a historical study of Mexican public policies and associated sociopolitical events is made, where it is observed that in each of the six years of the Government, women have taken steps to achieve this visibility, yet, conditions of inequality still continue from the conception of public policy to its implementation as government programs. They continue to highlight policies that target women in a role of mother and caregiver, and socially restrict their power in areas of public and private leadership that limit them in terms of work. Currently the feminine effort is directed to the change of social thought on the roles assigned in public policies through the acquisition of equity and justice.
\end{abstract}

\section{Keywords}

Women, Work, Public Policy, Visibility of Women, Women’s Rights

\section{Introduction}

The political rights of Mexican women have undergone changes throughout 
history. From their recognition as citizens to the creation of public programs with a gender perspective, women have had to make an effort to become visible both legally and in the workforce. However, what appears on paper to sound like a great achievement, the reality shows that it is still a work in progress.

The conception of the feminine role, from the beginning of the democratic life, has made it possible to propose different governmental actions through public policies to make women visible. Each public policy places women in a specific role and defines the actions that must be carried out. This reality, which may seem unfavorable, has made women aware of the actions they must take in order to be seen and heard.

This visibility is carried out in different areas such as that of legal, political, social and economic. This struggle has involved feminine actions that have had setbacks and limitations on the part of the government, however the constant effort has allowed for achievements such as acquired rights, labor benefits and the opportunity to decide their educational future. This is why it is necessary to recount the feminine actions and obtained successes without losing sight of the deficiencies that are still present in society which become points of new struggles for women in an effort to achieve a society increasingly fair and equitable.

Efforts will continue to generate a cohesion between women's needs and government actions which should be reflected in public policies with a sense of equality and that address the origin of the inequality.

\section{Method}

The aim of the article is to review, from a public policy perspective, the ways in which, through six-year presidential periods, official actions have taken place to make women come to light in laws and labor. It is carried out through political temporality, empirical and theoretical analysis. Therefore, the legal and public policy perspective in which the presidents of Mexico have included women and the way in which they have been considered over the years may be perceived from another angle. Methodologically it is a qualitative approach that enables one to examine in a remarkable way women's action and how it is reflected in Mexican politics. This is a historical study that explores the path that women have taken from the non-recognition by the law, up to the present time.

\section{Results}

\subsection{Women Rights in Mexico: A Balance}

In terms of human rights for women, the Federal Constitution has undergone changes that parallel the history of the country, reflecting changing societal mentalities and shaping daily life in areas that include family dynamics, educational practice, historical and socio-economic components, religious beliefs, and, undoubtedly, public policies. This dynamic has represented an oscillation from incipient acceptance to sharp rejection, from superficial admission to continuous negligence, from forced approval to passive resistance, from formal rec- 
ognition to the facto ignorance, from open discourse to excluding behavior, from expected visibility to observed invisibility.

A fundamental precedent, apparently juridical but essentially of political and psychosocial value, that clearly exposes this succession of variations goes back to 1857, with a proposal to pursue the rights of Mexican women, followed fifty years later by two simultaneous actions in 1917: the rejection of a proposal for the recognition of rights and the adjudication of her duties; until in 1953, as a result of efforts by feminist and suffrage groups, the first female suffrage took place. However, until 2017 Mexican women continue to be in a position of legal, social and political disadvantage.

The condition of equity (or inequity) in society has different ideological foundations. Specifically, the explicit position regarding gender equity in the last two centuries is related to three ideologies: Conservative, Liberal Democratic and Social Democratic (Table 1), in which given activities are assigned to the family, where certain types of gender relations and differentiated public policies are based on gender.

In Conservative Ideology, emphasis is placed on maintaining the existing social structure and traditional order; it is considered that the family is an essential institution that must be protected against the intervention of the State and the expansion of the public sector. In addition, this vision questions gender equality and government support for the entry of women into the working field, claiming that the function of the family within the social framework is reproductive. The ideology comes from the premise that women are not worthy of being considered in terms of public policies, but rather as a perceived entity based on their reproductive capacity. In this sense, the intention is to preserve the idea of the united family based on asymmetric and authoritarian relationships, from which an explicit gender differentiation is made, and policies are designed with a specifically masculine touch.

The Liberal Democratic Ideology is somewhat ambiguous because it attaches importance to family and gender relationships but sees the strength of it as the basis for social development and presents a balance between such development and public laws. It supports the idea that the role of women in society has a reproductive nature while also recognizing the need to legislate equality by designing some public policies that are of a neutral nature (for citizens) and others that are focused strictly on females.

Table 1. Taxonomy of gender policies based on political ideology and familial definitions.

\begin{tabular}{cccc}
\hline Ideology & Female Roles & Gender Relationships & Gender Policies \\
\hline Conservative & Reproductive & $\begin{array}{c}\text { Asymmetric and authoritarian } \\
\text { gender differentiation }\end{array}$ & Specifically, male \\
Liberal Democratic & Reproductive & Legislative Equality & $\begin{array}{c}\text { Neutral and specific } \\
\text { female }\end{array}$ \\
Social Democratic & $\begin{array}{c}\text { Productive } \\
\text { Reproductive }\end{array}$ & Tendency to gender equity & Redistributive \\
\hline
\end{tabular}

Source: [1]. 
Social democracy frames a transformation strategy for society through reforms based on political and social democracy, which in turn are based on the equality of living conditions and economic development with the public and popular control on the production system and services expansion. Within this paradigm, women not only have a reproductive function, but are also explicitly assigned a productive capacity; accordingly, there is a trend towards gender equity, as public policies acquire a distributive nature and there is an improvement in policies aimed toward women.

In parallel, with regard to the creation of these ideologies that support public policies, the disadvantages for women in Mexico can be observed historically within the framework that is built into the legal, social and political spheres. Within the legal field, the disadvantage is stated in the rejection of the first petition proposal for the practicing of Mexican women rights in 1917 [2], it is believed that this was a path to family disintegration. This places women at a legal disadvantage by not recognizing their citizenship rights as requested by women organizations in 1917 and because of 38 years delay until their right to vote was approved.

A social nature disadvantage is seen in the mindset that determines a single path for women due to the point-of-view that certain attributes are still exclusively feminine. This leads to stereotyped behaviors such as smoothness, obedience, sexuality restricted to reproduction, image protection of the male, and the restriction to a stay-home life (whose defects or narrow circumstances are beyond the scope of this paper).

The third set of disadvantages has been generated around practice of power limitation in public or private leadership positions, the occupational limits for women to a secondary role, understood exclusively as a co-responsibility to fill up the expenses for home maintenance and in the design of public policies restricted to that area.

The legislation derived from the Constitution of 1917 is the basis of the thesis of this work, which builds the argument that women in Mexico are still invisible, inaudible and second-class citizens, the thematic core idea is the legal, social, economic and political areas and are used in chronological sequence, linking the evolution of the law with the design of public policies and government actions aimed at women.

\subsection{Women throughout History}

Despite the fact that women and men are equal before the law, in Mexico there continues to be a great social disadvantage for women. Because they live in temporary or permanent conditions that affect their living and development, they are subject to cultural prejudices that do not take into account their individual qualities. While it is true that today women enjoy more freedom to exercise their rights as a partner, control the number of children they wish to have and the spacing between them, enjoy more opportunity to exercise a trade or a 
profession, and to participate in civil or political activities, it is also true that they continue to assume the main responsibility for domestic tasks and the care of their children, the sick, and the elderly in the home [3]. They face barriers that prevent them from having and enjoying more resources, greater opportunities, and the time necessary to develop their capabilities and achieve their wishes. All of this is accomplished by assigning traditional stereotypes and restricting women's involvement in the education system, labor market policies, and social security, all because they have been assigned a main role, almost exclusive of other options: mother and harmonizer.

Therefore, the trajectory of women's struggle for the recognition of their rights can be divided according to the themes in which they progressed little by little. From the request of their right to be recognized as citizens, through the request of access to education, their role as power of attorney of interpersonal relationships and care for others, up to their stigma in the cultivation of beauty and harmony in society. These struggles have represented a progress with both failures and achievements, but at each step they have represented an overall advancement in reducing the problem: the invisibility of women in society.

\subsubsection{Equal Rights, Equal Responsibilities}

The above has not been easy, as shown the attempt made by Hermila Galindo and Edelmira Trejo to send a letter to the constituents of Querétaro that was rejected by Venustiano Carranza with the following argument:

"Women have not left the domestic home circle, nor have her interests been disconnected from the household men; therefore, the family unit has not been broken. Women do not feel the need to participate in public affairs and this is demonstrated by the lack of collective movements" [4].

With this fact sits a point for consideration, initially raised in 1857 and remaining on the agenda for almost 150 years, before Mexican women were granted the right to vote. There is evidence that the 150-year delay was not necessarily a matter of rights, but a matter of votes. In 1938, during the presidency of Lázaro Cárdenas, a bill was sent to Congress to guarantee the right of men and women to vote and to receive votes, nevertheless, a lapsus mentis of the deputies produced a forgetfulness consisting in excluding from the agenda, the initiative to vote, on the thinking that, upon approval, the opposition parties would be stronger. That omission was corrected in 1946, when the initiative for women's votes in municipal elections was approved [2]. At this time, the candidate to become a city mayor, Miguel Alemán Valdez is the winner of the contest.

\subsubsection{Education for All}

The social movement with the goal of claiming for women the same rights that existed for men, led them to hold the first feminist Conference in Yucatan in January 1916 [4]. The central topic of the congress was the integration of women as citizens.

In addition, one of the main issues addressed, was the right of women to 
access education. Related to this and because they could already have access to education, it is assumed that this could determine in which areas women could work.

A favorable outcome of the Yucatan Conference was the discussion about the promotion of basic education in a formal way for women. Since the acquisition of this right, the access of women to different educational levels has gradually increased.

In general, women's access to education and basic literacy have positive consequences for their health and their families [5], although the right to education does not guarantee that it is pursued by the majority of female population. For example, the state of Guanajuato is currently among the first places to offer basic education [6]. However, the dropout rate for women is higher than men; as the level of educational attainment increases (from secondary to higher education), the proportion of female dropouts increases in general and compares to male, not only in terms of access [7], but also graduation and degrees [8]. This dynamic of reducing schooling is linked to an aging mentality, and leads to impoverishment of the female population [5], a high rate of teenage pregnancy [8] [9] and in turn, as a consequence, high rates of maternal mortality [10]; as well as young people living together at a young age [8].

As an advantage of access to education, the assortment of work is extended. Between the nineteenth century and the first half of the twentieth, it was explicitly accepted that women could work outside the home only in matters related to nursing. The rationale was that their role as homemakers and as caretakers of their parents, children, and/or husbands, particularly in times of illness, allowed them to acquire the necessary skills for nursing. Later, it was thought that while educating the children, women developed teaching skills. Therefore, it began to be seen as acceptable for there to be a division of work outside the home in which women "broadened their horizons" by serving as assistants to teachers or nurses.

\subsubsection{Take over Interpersonal Relationships: Caring for Others}

Within the assumptions and dimensions that give rise to the female stereotype is the assignment of the woman as the main person responsible for the management of interpersonal relationships and the care of others. In general, public policies in Mexico [11] allude to a supposed natural vocation, a particular way of life that women should have (without being as drastic as the position of religious institutions that limits them to motherhood and virginity) [12], to a presumably rational choice of role and a radical and differentiated opposition of the attributes and roles that exist between men and women. In this paradigm, a distinction is made in the sense that women are sometimes needy recipients, but at the same time passive and inaudible ones, because it is assumed that men must provide the material needs of women, and it is considered that the demands and interests of women stem from issues of reproduction and family care. Certainly "Affirmative Action Policies" have been designed and applied in favor of Mex- 
ican women. These Policies have yielded development as they are targeting specific problems restricted to a moment and the issues to which women have been limited.

\subsubsection{Cultivation of Beauty, Delicacy, and Harmony in Society}

In this field, until the beginning of the twentieth century, the main reason why the house was considered the place for a woman is because boys in the house needed the care of the woman to grow into men; now it is recognized that there are also girls growing up in the house. Women, therefore, tried to ensure that the children had a healthy childhood (and nowadays, also a healthy adolescence). Her participation focused on raising of that boy-yes, a boy, not a girl-as a good, profitable male. The women were the ones who had to be in charge of the house, the children, and also be the exemplar mother and wife.

Women were allowed to do only what was right for their gender. However, the ones who determined what that meant, were men. Therefore, at the Yucatan Conference of 1916, there was an intention to break with the idea that only unattractive or indigent women were allowed to get involved in issues such as social support or charitable aid. A goal of this feminist social movement was to ensure that all women had the right to work, that they were not spatially or thematically limited to domestic issues nor to exclusively being involved in issues and actions of charity or religion, but that they could actively participate on their own education, direct their own educational interests, and choose their job.

\subsubsection{To Fulfill the Reproductive Function}

Within the framework of public policies, women were considered to have a reproductive function. This led the Government to create the National Program for the Integration of Women in Development and the Family Planning Program (1978). This policy was implemented during the administration of President José López Portillo y Pacheco. The program is aimed to family women of reproductive age.

These programs involve having workshops and creating awareness about family planning in couples. This is as a formal initiative to encourage birth control and to reduce maternal mortality.

\subsection{Public Policies to Fulfill the Family Function, the Provider Role and Paid Employment}

A general recount of public policies is correlated with the specific events that mark the continuity of the country's social and political course (as shown in Table 2). In a dynamic in which the female population manifests itself in favor of its visibility in the social field and the political movement, and it is observed that the action of the State and the government in terms of social, economic, political and juridical terms was given slowly in a greater space of action and support to promote equity for women. A strong component is a socio-economic one as a poverty reduction strategy has been carried out with programs aimed at women, 
Table 2. Timeline in Mexico on the evolution of public policy, programs, national events and changes in laws that improved the visibility of women.

\begin{tabular}{|c|c|c|c|}
\hline Year & President & Programs, Public Policy, National Events, changes in laws & Kind \\
\hline 1896 & Porfirio Díaz & $\begin{array}{l}\text { In Chiapas, the first elementary school for women is founded, in Chihuahua the industrial } \\
\text { school for Young Girls was founded. The memories about the States relating the 19th } \\
\text { century is created. }\end{array}$ & Social \\
\hline 1916 & Venustiano Carranza & First Feminist Conference in Yucatan. & Sociopolitical \\
\hline 1923 & Álvaro Obregón & First Feminist Conference of the Pan American Women's league & Sociopolitical \\
\hline 1925 & Plutarco Elías Calles & Chiapas recognizes the equality of political rights for men and women. & Legal \\
\hline 1935 & Lázaro Cárdenas del Río & Creation of the Single Front for Women's Rights 1935 & Social \\
\hline 1937 & Lázaro Cárdenas & $\begin{array}{l}\text { Recognize in front of the Law, women have the same rights as men as Mexican citizens. } \\
\text { Initiative for the reform to article } 34 \text { in the Constitution. }\end{array}$ & Legal \\
\hline 1946 & Miguel Alemán & $\begin{array}{l}\text { The political rights of women to participate in the City elections are approved. } \\
\text { Constitution Reform to Article } 115 \text {. }\end{array}$ & Legal \\
\hline 1959 & Miguel Alemán & $\begin{array}{l}\text { The services of the Mexican Institute of Social Security (IMSS) were extended to the } \\
\text { workers' families. }\end{array}$ & Socioeconomic \\
\hline 1952 & Adolfo Ruiz Cortinez & $\begin{array}{l}\text { Initiative of law to guarantee the political rights of women to vote and to be voted as well } \\
\text { as the recognition as citizens without making the distinction between men and women. }\end{array}$ & Legal and political \\
\hline \multirow[t]{2}{*}{1953} & \multirow[t]{2}{*}{ Adolfo Ruiz Cortinez } & $\begin{array}{l}\text { Rural Social Welfare Program. The goal was to have Pre-school; children's breakfast bars; } \\
\text { cutting, sewing, confection and arts and crafts lessons; cooking and food canning, as well } \\
\text { as mother's clubs for women to acquire knowledge of childcare and home finances. }\end{array}$ & Social \\
\hline & & $\begin{array}{l}\text { Articles } 34 \text { and } 115 \text { in the Constitution are amended to guarantee the vote of women and } \\
\text { their possibility to participate in an election. }\end{array}$ & Legal \\
\hline 1953 & Adolfo Ruiz Cortinez & $\begin{array}{l}\text { Building centers in which women received practical lessons for the benefit of family } \\
\text { members. }\end{array}$ & Social \\
\hline \multirow[t]{2}{*}{1958} & \multirow[t]{2}{*}{ Adolfo López Mateos } & & \\
\hline & & $\begin{array}{l}\text { At the same time, the first election of a woman in a popular election position, as a Mayor } \\
\text { was held. }\end{array}$ & Political \\
\hline 1959 & Adolfo López Mateos & $\begin{array}{l}\text { Mothers with formal employment had access to day care centers for their children, only } \\
\text { close to work centers where more than } 50 \text { women worked. }\end{array}$ & Socioeconomic \\
\hline 1970 & Luis Echeverría Álvarez & $\begin{array}{l}\text { Peasant women of the ejido (Common) were recognized as agrarian subjects and were } \\
\text { given land to form industrial agricultural units }\end{array}$ & Socioeconomic \\
\hline 1971 & Luis Echeverría Álvarez & $\begin{array}{l}\text { An Agroindustry Units Program of for Women. The objective was that peasant women of } \\
\text { the ejido (common) were recognized as agrarians and were given land to form industrial } \\
\text { agricultural units in which they could achieve productive tasks for collective benefit. }\end{array}$ & Socioeconomic \\
\hline 1974 & Luis Echeverría Álvarez & Women's liberation movement. & Political \\
\hline 1975 & Luis Echeverría Álvarez & First registry of women's associations & Political \\
\hline 1976 & Luis Echeverría Álvarez & Feminist women coalition. & Political \\
\hline 1978 & $\begin{array}{l}\text { José López Portillo y } \\
\text { Pacheco }\end{array}$ & $\begin{array}{l}\text { Family Planning Program, a program that benefited society but was aimed to } \\
\text { homemakers. }\end{array}$ & Social \\
\hline 1979 & $\begin{array}{l}\text { José López Portillo y } \\
\text { Pacheco }\end{array}$ & National Front for the liberation struggle & Political \\
\hline 1980 & $\begin{array}{l}\text { José López Portillo y } \\
\text { Pacheco }\end{array}$ & National Program for the Integration of Women to Development, (PROMAN) & Social \\
\hline 1981 & $\begin{array}{l}\text { José López Portillo y } \\
\text { Pacheco }\end{array}$ & First National Assembly for women & Social \\
\hline
\end{tabular}




\section{Continued}

\begin{tabular}{|c|c|c|c|}
\hline 1982 & Miguel de la Madrid & Program for the integration of women to development & Socioeconomic \\
\hline 1982 & Miguel de la Madrid & Support in day care centers, for children care. & Socioeconomic \\
\hline 1983 & Miguel de la Madrid & $\begin{array}{l}\text { Action Program for the Participation of Peasant Women in the Achievement of Rural } \\
\text { Development, (PROMUDER) }\end{array}$ & Socioeconomic \\
\hline 1984 & Miguel de la Madrid & Community Development Program with the Participation of Women, (PINMUDE) & Social \\
\hline 1985 & Miguel de la Madrid & Program of Support to the Productive Projects for Peasant Women. (PAPPMC) & Socioeconomic \\
\hline 1989 & Carlos Salinas de Gortari & $\begin{array}{l}\text { Women in Solidarity, (MUSOL), of the National Solidarity Program, (PRONASOL) These } \\
\text { programs emphasized the participation of women in the communal management of } \\
\text { productive work as a key element in overcoming poverty. Over time it has changed its } \\
\text { name: Progresa, Oportunidades, Prospera. Its objective is maintained because the } \\
\text { program is integrated by three closely linked components: educational economic support, } \\
\text { basic health care for all family members, and support to improve food consumption and } \\
\text { nutritional status of families in situational poverty. }\end{array}$ & Socioeconomic \\
\hline 1991 & Carlos Salinas de Gortari & Program for Peasant Women. & Socioeconomic \\
\hline 1996 & Ernesto Zedillo & National Program for Women Alliance for Equality & Socioeconomic \\
\hline 1996 & Ernesto Zedillo & National Program for Women. & Political \\
\hline 1998 & Ernesto Zedillo & Microfinance Fund for Rural Women FOMMUR & Socioeconomic \\
\hline 1999 & Ernesto Zedillo & Program for Organized Groups of Women in Rural Development & Socioeconomic \\
\hline 2000 & Vicente Fox Quesada & Women Entrepreneurs-Women Producers Program & Socioeconomic \\
\hline 2000 & Vicente Fox Quesada & Women in Rural Development Program & Political \\
\hline 2001 & Vicente Fox Quesada & National Program for Equal Opportunities and Non-Discrimination against Women. & Political \\
\hline 2001 & Vicente Fox Quesada & National Program for Equality amongst Women and Men & Political \\
\hline 2002 & Vicente Fox Quesada & Program for women in the agricultural sector, PROMUSAG. & Socioeconomic \\
\hline 2003 & Vicente Fox Quesada & Health and Nutrition Program for the indigenous people. & Social \\
\hline 2004 & Vicente Fox Quesada & Decree of Law to the creation of the National Institute for Women & Political \\
\hline
\end{tabular}

2005 Vicente Fox Quesada Women heads of family's income opportunities Program, with the objective of providing productive support and loans to low-income entrepreneur families and social enterprises.

Socioeconomic

National Agreement for Equality amongst Women and Men, where the promotion of equal treatment and opportunities among women and men was raised to the rank of national priority, and the necessary commitments were adopted to comply with laws and

2007 Felipe Calderón Hinojosa international agreements that guarantee a life free of violence; guide strategies to eliminate discrimination and promote equal treatment for women and men in the public and

Political private spheres; to assume the principle of equality as the guiding principle of the plans and actions of all the governing bodies; and promote the adhesion of all the governmental and social instances to this agreement.

2008 Felipe Calderón Hinojosa Start-up and Strengthening Fund for Municipal Women’s Instances 2007

Political

PROEQUIDAD fund, in its sixth issue, with the purpose of strengthening social

2009 Felipe Calderón Hinojosa $\begin{aligned} & \text { co-investment projects between the government and civil society organizations aimed at } \\ & \text { improving the living conditions of the female population in priority issues, groups or }\end{aligned}$

Socioeconomic regions

National Program for Equality among Women and Men 2007-2012. Program on Productive Projects and Employment for Women: Interinstitutional Table of Support

2010 Felipe Calderón Hinojosa Programs, with the objective of helping the entities that manage programs for the development of productive projects and employment for women, comply with the regulations regarding equal opportunities and gender. 


\section{Continued}

\begin{tabular}{ccc}
\hline 2011 & Felipe Calderón Hinojosa & Childcare and Nursery Program to Support Working Mothers \\
2011 & Felipe Calderón Hinojosa & Women and Health Program, the Ministry of Health since 2003. \\
2014 & Enrique Peña Nieto $\quad$ Support Program for the Productivity of Enterprising Women
\end{tabular}

Source: [13] [14] [15].

and since then, in the last thirty years, it has been recognized that women can take better advantage of socio-economic development programs and respond to the commitments that are required to be beneficiaries of the same rights as men.

\subsubsection{To Fulfill the Family Function}

The family function is understood as the woman's responsibility to face the problems and meet the needs generated in the care of children. For this reason, the Rural Social Welfare Program was created in 1953 [13].

This program included the construction of kindergartens, children's breakfast bars, cutting, sewing and tailoring lessons, arts and crafts, cooking, food canning; mothers' clubs; In these clubs, women acquired childcare and domestic finances knowledge.

It is observed that despite being a public program that entirely addressed women, they are still kept in their naturalized role as housewives and mothers.

\subsubsection{To Fulfill the Domestic Function}

As one of the functions in which women have been pigeonholed, the domestic function relates to the responsibility of home care.

Attention is paid to women only as mothers or housewives; their activity on the labor field, whether as a head of family or as a provider, it is considered an exceptional situation. Only those who did not have someone who would financially provide for the household were allowed to participate in the labor field.

As passive entities in the market, the domestic function allows women to access the social security offered by the Mexican Institute of Social Security, IMSS. This, with a small variant, only the wives or daughters of the workers had access. Therefore, it was not considered that there were workers who could have access to this right.

\subsubsection{To Fulfill the Role of Provider and the Previous Three}

During the administration period of President Luis Echeverría Álvarez (1970-1976), the Women's Agroindustry Units Program was created. As the first program aimed to women living in poverty, and in conjunction with another group of programs whose target population was rural women, this is considered the beginning or the path not only for women's access to the so-called modern sector of the economy [13], but also for Mexico to be considered within modern economies.

The evolution of programs, public policies, national events or legal changes that have impacted the visibility of women from the governmental perspective 
over time (Table 2) have become relevant due to the active participation of women in different forums. Since 1986, women have begun to be considered participants in the educational field, and in 2014, women acquired the possibility of obtaining loans to be entrepreneurs. Over the course of time, there were stages in which the type of attention depended on the thinking and conception that women had with regard the role they played in family and in society.

\subsubsection{Paid Employment}

At the beginning of the 1980s, women began being considered as development participants, whence initiatives that promote women's employment and self-employment have been created. These programs are based on training and education for women. The National Program for the Integration of Women in Development [13] was designed and established to improve women's conditions.

This program represents a milestone, as there was a need to enrich women's image by recognizing and promoting their role as workers, providers and citizens, in addition to their role as mothers. Production and professional training workshops were developed; the support was encouraged through day care centers.

Thereafter, this would be par excellence the strategy for the integration of women to development [13].

\subsection{The Glass Ceiling}

There is a situation for women, called the Glass Ceiling [16], which refers to an invisible upper surface through which women cannot easily pass, preventing them from advancing in their careers. The Glass Ceiling has some variants and incidences both in public and private sectors, which prevents women from claiming a "Differentiated Individuality" [17]. That she limits her own self or internalizes the invisible borders society places for her development.

One of those variations is that women themselves, even when they are aware of the situation, they look like they don't. Also, that they avoid exposing to be more efficient than the men with whom they interact, not necessarily with their partner, but with the whole society in which they thrive. A third variant is in their collaboration, consciously or unconsciously, with the patriarchal pact, in which women can hold power in terms of organization, as happens in some micro-enterprises [18] of a family nature in which the women of the family manage the business but "let the man work at the cashier or taking care of the government formalities" so that he does not feel evicted. This also occurs in big companies which have the capacity to promote women but instead restrict them to middle positions due to the implicit discriminatory codes that do not allow female advancement.

Even when the civil code of 1881 gave unmarried women almost the same rights to men, those rights were removed at marriage [19]. From 1946 to 1968, women's training centers were established [13] in which women received practical training, but only of the kind and nature that would benefit the develop- 
ment of the family members where they belonged or which they were taking care of.

According to this, it was thought that in order to be considered as providers, women would have to lack of a man and male support. In that case they were considered as marginal or disadvantaged individuals, and, in that sense, they could be granted the "permission to work" and receive benefits. This is contradictory, as a woman is considered vulnerable without protection by a male, but in many cases, it is precisely the asymmetric relationship with the male that places them in a position of vulnerability given the relationships of violence, not only financial but also physical and mental.

\subsection{Political Disadvantage}

Finally, on the politics sphere, disadvantages for women are seen narrowing to power in legislative, judicial and executive governmental institutions, as well as in private institutions, whether lucrative or not-for-profit.

\subsubsection{Narrowing the Exercise of Power in Public Leadership Positions: Popular Election}

The possibility for women to reach popular election positions was accomplished in 1958 where, for the first time in history a woman holds a position as a mayor in Dolores Hidalgo, the birthplace for national independence. Even though her term was relatively short (1958 to 1959), she set a precedent for other women in other States and cities, to contend for public office.

Nowadays, there are public policies and affirmative actions that allow women to have slots in the public life of the Country. Each one from different methodological aspects looking to cut back the gender gap is expected to be in cut back.

An affirmative action that has started is the gender quota, which means to reserve a slot for a certain percentage of women in decision making positions or for political candidacies.

This practice, which at first, contributed to the active participation of women in political life, has become a simulation mechanism. Once they take office, women decline in favor of their substitute, who is usually a man.

The advance of women's political rights began with their struggle for obtaining the right to vote in the city elections in 1947 and concludes with the grant of the right to vote on the federal elections in 1953. Aimed at this achievement, Constitutional article 34 was reformed, women recognized as Mexicans and as citizens of the republic, also constitutional article 115 is reformulated, women have a full right to vote and be voted on the same standing as men.

\subsubsection{Narrowing the Exercise of Power in Private Leadership Positions}

By recognizing women as Mexican citizens with the same rights as men, a more independent inclusion in the labor field is allowed. Thus, women could not only access to elected but also leadership positions in companies and business centers. However, nowadays educational and financial opportunities do not follow this 
disposition either in the income, access to education, job position, salary or paid work.

\subsubsection{Prospective in Public Policy}

Now, once it has been shown that women, even after being recognized in front of the law, remain invisible in other areas, we return to the beginning. What characteristics should be bear in mind in a public policy definition, in order to make women visible?

First there must be objectives and strategies that define the steps to follow to implement them; second, they require sufficient financing which considers each stage until its end; third, they must have a certain time, a public policy has a period to fulfill its functions and objectives; and fourth, they must be conclusive, that is, they must reduce, reduce or eliminate the problem according to the goals and objectives shown.

Putting these elements together in an organized manner and communicating their purpose could lead to gender equity. The description of the main elements of public policy does not represent inventing the wheel, nor does it guarantee efficiency in its implementation or the achievement of results, or make women more visible and audible, but it does represent a fundamental starting point and wording of the route that must be followed so that a public policy is successful. In this sense, the theories of how public policies are made show us a route and the elements to be taken into account. It is important to identify if in everyday life these elements are considered by governments at the moment in which they create a public policy to make women visible and audible.

However, referring to the visibility and audibility of women in the process of developing a public policy raises a series of realities that happen with respect to what should happen. Regarding the goals, it is expected that women will be considered in the field of action and policies; however, simultaneously with these goals, measures must be generated to improve the conditions of women and covering their needs completely.

Regarding the action plans and the construction of public policies, there must be a guiding thread, which must guarantee access for all women to the benefits that arise in participation with society. The reality in Mexico indicates that society is not yet ready to exercise its voice, therefore it does not participate in decisions in a plural way; the women themselves do not participate in decisions that concern them. One of the reasons is that the necessary spaces have not been provided for women to prepare themselves, for them to get them and for men to accept it.

Regarding the operation, it is observed that the implemented programs are transversal and from them real results and direct benefits are expected. However, there are certain problems such as the creation of programs or public policies "with a gender perspective" without thinking about the needs of women and without financing. With certainty it can be said that general public policies must be made, including certain affirmative actions towards the rights of women that 
allow to limit existing inequality and include sufficient financing to execute them.

In relation to time, the main premise of a public policy is that it must be limited, that is, it must have a certain time. The actions of public policy must be limited to the problem and the solution. For example, regarding affirmative actions, the idea is to generate all the conditions for women to cover the need that must be addressed, to make the gap visible and reduce it, but not to turn them into permanent social assistance programs.

Coupled with the above is the strength of public policies, that is, they address a specific problem and conclude with the eradication of it. This is a delicate point, because a program must last long enough and necessary for the attention of the detected problem and the guarantee that it will be understood and resolved. This means that defining how long a program or public policy will last is a function of the magnitude of the problem to be addressed, but above all of the strength of the policy itself.

This recount of events shows that actions to recognize women as citizens and include them explicitly in society are generated as much within society as in the political strategy of the Mexican state. It also shows that mere legal reform does not guarantee the visibility of women, but that an appropriate public policy goes more in that direction and that its application can also promote the change of mentalities that make the voice and presence of women acceptable in society.

\section{Conclusions}

What is it that makes the difference between being visible and invisible? What does it mean to be visible? What does it mean to be audible? What does it mean to be invisible and inaudible? The following polarizations highlight some examples of what is equivalent to integrating public policy with everyday life, with the understanding that certain private problems are political because these problems are shared by many women and are not due to individual deficiencies, but to patriarchal structures [17]: social agent versus others' appendix. To be visible is to be a social agent, to be an independent and respected person as such, not as an appendix of the hierarch in turn (as the father or husband is still considered).

Majority versus minority: To be audible is to be a citizen, to be recognized as of legal age be audible is to have a voice and not to be silent, it is to exercise the right to have an opinion; to be audible is to stop being submissive, fulfill obligations and have a life with good quality. Fair and equitable compensation against precarious remuneration: To be visible is to have work equal to equal pay, is to promote the application of Article 123 of the Constitution; to be visible is not to receive lower salaries than men with the prejudiced arguments that their trajectory as a mother ("mommy track") subtracts a woman from concentration in work that she lacks commitment to keep working, that this is not relevant because "as a woman, she will take employment as something temporary", because it's still thought that it is normal for women to be unemployed, despite the fact 
that a quarter of Mexican households have women as heads of family [20].

To be visible is to exercise the right to planned and voluntary motherhood, to be visible is to stop believing that the right to motherhood would have to be (self) restricted for wanting to exercise also the right to work. Many women confront the claim that in order to access certain jobs, no commitments should be made; here there is an interesting issue before the decision (disjunctive) to work or have children, it is about the rotation of the staff, which is higher among young people and those who do not have children. However, there is the prejudice of women who will leave work more easily because, as has been said, it is believed that their primary task is to care for the family and the home; in fact, the fact that the couple demands to be cared for by the woman also pretends that she remains in the home.

To be audible is to recognize in the intimacy of the home that the responsibility and duty of procuring the children belong to women and men. Being visible also crystallizes with the possibility that women are providers and not only administrators of those who provide. Being visible and audible is also being the owner of your sex, is exercising and exploring sexuality, is not restricted to the reproductive task; to be visible and audible is to feel sexual pleasure when one decides and not by the demand of others, nor in the purpose of satisfying the pleasure of others and not of oneself, not living in the apparent romance when the male demands it and thus fulfill a bearable end. When the woman becomes audible and visible, she can stop being a victim of violence.

\section{Prospects}

The course to equity. Just as gender inequality was built throughout history and remains in the mentality of many individuals, in the name of justice and dignity it is necessary that society, women and men, form a perspective and a life where the rights of all people are guaranteed: not only in the norm, but in the daily practice. Some reflections aimed at the visibility and audibility of women close this chapter, place on the agenda the need to design public policies that allow people to learn and generate individual strategies to coexist with gender awareness and acceptance of multiculturalism.

First, recognize that people live similar experiences in their development, while they are unique and, therefore, contribute differentially in their environment; It is a dialectical relationship that builds the diversity of humanity. This principle is repeated in terms of gender: women and men are different and follow different paths, the acceptance of this can lead to gender equity. It is about the rights and advantages that men have traditionally had to expand and reach women.

Second, the recognition of the rights and obligations of men and women must be, not a law of paper or dead letter, but an experience, a Commitment. The fact that the principle of equal citizenship is stipulated in the Constitution since 1917, that subsequent reforms have come to recognize the rights of women, or 
that in recent times the Law on Women's Access to a Life Free of Violence has been enacted are advances on the road to equity, but it does not mean that these modifications are fully complied with nor that they guarantee a fair and peaceful life. It is not enough that they are there, nor that they know they are there; it is to include forms of communication and conviction that equity must be built in daily life, which must be present on a day-to-day basis.

Third, domestic work is essential to ensure the health and hygiene of household members. The household supply is its complement. The possibility of each individual enjoying a clean and friendly environment is the responsibility of all, of men and women. Hence, the equity between men and women happens because the socialization of both includes the attention of other people in the home, the care of the environment, the procurement of physical and mental health, the development of autonomy.

We also have that in the work there is no exclusivity of gender, we all use dishes and we would all have the obligation to wash them. Both men and women are co-responsible and both have the obligation to fulfill our responsibilities, with the obligation to provide women and to achieve a certain step does not mean that men descend one but that we will be on the same step.

Fourth, the law fulfills its function of having adequate regulations, the country has a complete set of laws, but it is society's responsibility to enforce them, all and everyone.

Fifth, public policies must have a sense of fairness; programs, actions and governments must have clear goals, anti-discrimination definitions and spaces for the participation of the population. As citizens, not only as women, we should be trained and interested in knowing what the law grants, what governments offer and how they offer it, to put the bit that will allow us to obtain what corresponds to us in justice.

Finally, public policies must address the origin of inequality, while affirmative actions have to address the consequences. What does this mean? This means that an affirmative action can shorten in a short time the gap that exists between men and women. For example, the gender quota allows women to be elected quickly in certain positions of popular election and for women to learn to exercise their right in political life. But then, what should public policy do? Public policy should ensure that in the next generation all citizens have the same education and a better education so that they do not have to "do something extraordinary" (such as establishing quotas) so that women by their own trajectory are ready to access that position. Certainly, one of the perspectives in legal, political and social matters is that the mentality of our society guarantees that through the woman being prepared she demands that her peers be also. That is one of the responsibilities and rights that, at least in the Constitution, we have. It is a pending subject to make it a reality.

\section{Conflicts of Interest}

The authors declare no conflicts of interest regarding the publication of this paper. 


\section{References}

[1] Dahlström, E. (1989) Theories and Ideologies of Family Functions, Gender, Relations, and Human Reproduction in Changing Patterns of European Families Life. A Comparative Analysis of Fourteen European Countries. Routledge, London.

[2] Instituto de la Mujer Guanajuatense (2014) Mujeres. Gobierno del Estado de Guanajuato, Guanajuato.

[3] ONU (2012) Informe El Progreso de las mujeres en el mundo (2011-2012): En búsqueda de la Justicia. ONU, New York.

[4] Mora, M. (1985) La igualdad jurídica del varón y la mujer. Conapo, México.

[5] UNDP (1995) Human Development Report. Oxford University Press, New York.

[6] SEG (2016) Dirección General de Planeación, Programación y estadística educativa. http://www.snie.sep.gob.mx/estadisticas educativas.html

[7] Guevara Sanginés, M., Woitrin, E., Martínez-Hernández, A.C. and Rodríguez Partida, H. (1997) Y quién desea estudiar en la Universidad de Guanajuato? Censo de Aspirantes a licenciatura 1997. Universidad de Guanajuato, Guanajuato.

[8] Cedoc (2016) Mujeres y hombres en México 2016. Inmujeres, México.

[9] Welti, C. (2000) Análisis demográfico de la fecundidad adolescente en México. Papeles de Población, 6, 26.

[10] Freyermuth, G., Luna, M. and Muñoz, J.A. (2016) Indicadores 2014. Mortalidad Materna en México. CIESAS, México.

[11] Franco, J. (2015) Diseño de políticas públicas una guía práctica para transformar ideas en proyectos viables. IEXE, México.

[12] Juan Pablo, I.I. (1988) Mulieris Dignatatem. Librería Editrice Vaticana, Rome.

[13] Tepichin, V.A.M., Tinat, K. and Gutiérrez de Velasco, L. (2010) Política pública, mujeres y género. Los grandes problemas de México. Relaciones de Género, 8 , 23-58.

[14] Mungarro, F. (2002) Mujeres rurales y procesos organizativos en México. In: Memoria del Seminario Internacional: Revalorización de los grupos prioritarios en el medio rura, Sagarpa, México, 187.

[15] Presidencia de la República (2000-2014) Informe anual de Gobierno. Oficina de la Presidencia de la República, México.

[16] Griffiths, S. (1996) Beyond the Glass Ceiling. Manchester University Press, New York.

[17] Millet, K. (1969/2010) Política Sexual. Cátedra, Madrid.

[18] González Villafaña, N.K., Martínez-Hernández, A.C., Guevara-Sanginés, M.L. and Alonso-Guerrero, J. (2011) Autorregulación en una familia de microempresarios. Memorias del VIII Encuentro Participación de la Mujer en la Ciencia. Gto, León, mayo 2011.

[19] Vallens, V. (1975) Working Women in Mexico during the Porfiriato 1810-1910. California State University, San Francisco.

[20] Inegi. (2016). http://www.inegi.org.mx 